\title{
An economic analysis of role of technology in sustaining water resources for enhanced agricultural production
}

\begin{abstract}
Sugar producing regions in India have more than 80 percentage groundwater irrigation through deep-well pumping. Whereas, NASA's gravity recovery and climate experiment satellites have revealed faster depletion of groundwater stocks in India. These areas are cultivating 93 percentage of sugarcane. This research is a comparative study and has attempted to estimate the economic value of irrigation water and the benefits of water and energy that can be saved through adoption of improved irrigation technologies. The economic value of each ha. $\mathrm{cm}$ of irrigation water for sugarcane was also worked out. Including additional area under irrigation with the water saved should be recommended only in safe and semi-critical regions to prevent 'rebound' effect.
\end{abstract}

KEY WORDS : Water saved, Energy saved, Micro irrigation, Rebound effect

How to cite this paper : Priyanka, P. Asha and Chandrasekaran, M. (2015). An economic analysis of role of technology in sustaining water resources for enhanced agricultural production. Internat. J. Com. \& Bus. Manage, 8(1): 64-69. 